Marta ToMczok

Uniwersytet Śląski

\title{
Od inter- do trans-: ciemne źródła sztuki Erny Rosenstein
}

Ciemnym źródłem literatury i sztuki Erny Rosenstein jest nie tylko rozumiana jako doświadczenie ludobójcze Zagłada, ale głęboko przeżyta przez artystkę śmierć rodziców, zamordowanych w 1942 roku podczas ucieczki z Krakowa do Małkini. Zabójstwo, którego artystka była świadkiem, zaciążyło na całym jej późniejszym życiu przede wszystkim jako zdarzenie prywatne, pozbawione rysu historycznego, niedzielone z innymi, odizolowane od masowego dramatu. Niezależnie od okoliczności pojedyncza śmierć, która wydarzyła się równocześnie z tysiącami innych żydowskich śmierci pewnej nocy na początku lat czterdziestych ubiegłego wieku w lesie, $\mathrm{z}$ dala od cywilizacji, stała się dla członkini Grupy Krakowskiej i wybitnej polskiej surrealistki wydarzeniem mitycznym, upostaciowionym za pomocą symbolicznych odcisków realnego. Ich splot, nazywany przez Ernsta van Alphena wizualnymi śladami (visual imprints) (van Alphen 2019: 78), dał początek jednej z najbardziej idiomatycznych ścieżek, jakimi poszła polska sztuka po Holokauście. Istotę fenomenu twórczości Rosenstein stanowi połączenie tego, co publiczne i prywatne, historyczne i indywidualne, wspóldzielone i niepodzielne, widzialne i niewidoczne, pojedyncze oraz zbiorowe (Juchniewicz 2019). W świetle ogólnych obserwacji ważne wydaje się uchwycenie złożoności doświadczenia historycznego, jakim była dla Rosenstein Zagłada, oraz wyjaśnienie jego indywidualnych i ponadindywidualnych przemieszczeń, a następnie odniesienie ich do reprezentacjonistycznych możliwości sztuki 
i literatury, ich wzajemnego oddziaływania, a także zagrożenia utratą zdolności do przedstawiania, jakiemu podlegają.

W środku tych dyskusji znajduje się obraz. To on jest ciemnym źródłem. Krzyki rodziców w lesie, szarpanina ze szmalcownikiem, światło księżyca i błysk zakrwawionego noża składają się na doświadczenie traumatyczne o charakterze wizualnym, wymuszające złożenie naocznego świadectwa. Towarzyszą mu takie afekty jak: gniew, lęk, pragnienie zemsty. Z upływem czasu pamięć szczegółów przestaje być wyraźna. Właśnie wyraźna, a nie dotkliwa - bolesność, spowodowana mętniejącym wzrokiem, zdaje się rosnąć wprost proporcjonalnie do utraty przez pamięć ostrości. W przypadku artystki wpływ na postępujące zapomnienie miały także jej kolejne doświadczenia z okresu wojny i okupacji, a zwłaszcza czas spędzony po „stronie aryjskiej” w Warszawie i Częstochowie. Osłabienie pamięci morderstwa rodziców mogła także warunkować utrata archiwum domowego Rosensteinów, a szczególnie pamiątek po najbliższych, albumów i portretów ${ }^{2}$. Tego więc, co stanowi materialne medium pamięci, pozostające w polu sztuki użytkowej.

W 1945 roku, po powrocie do Krakowa, artystka spotkała przypadkiem fotografa, u którego jej rodzina robiła przed wojną zdjęcia. Udało mu się ukryć pod ziemią archiwum zakładu fotograficznego i w ten sposób ocalić także negatywy zdjęć rodziny Rosenstein, które następnie przekazał artystce. Jak pisała Dorota Jarecka, nie sposób dziś ustalić, które zdjęcia zostały wywołane z otrzymanych negatywów, a które podarował Rosenstein po zakończeniu wojny brat:

Ważne jest zdanie sobie sprawy, że powracające w [jej - M.T.] sztuce portrety rodziców rysowane są i malowane w odniesieniu do zdjęć. Że nie jest to prosta historia relacji podmiotu do własnej pamięci. Pomiędzy podmiotem a przedmiotem, między córką a rodzicami, pomiędzy córką a jej pamięcią o rodzicach, między pamięcią a obrazem, jaki pamięć jest w stanie tworzyć, znajduje się jeszcze ten na pół materialny obiekt, jakim jest fotografia (Jarecka, Piwowarska 2014: 82).

1 Pod wieloma względami lepszą kategorią jest tu scena, rozumiana jako sekwencja obrazów zapamiętanych w mgnieniach.

2 Bodaj najbardziej znaną interpretację zdjęć i ich znaczenia w przypadku odzyskiwania pamięci Zagłady zaproponowała Marianne Hirsch, powołując się na stanowiska Rolanda Barthesa i Susan Sontag: „[...] indeksalny charakter fotografii, jej rola szczątka, śladu czy fetysza - jej bezpośredni związek z materialną obecnością osoby fotografowanej wzmacnia jej status jako zwiastuna śmierci i równocześnie jej zdolność do oznaczania życia” (Hirsch 2010: 250). 
W przypadku zdarzeń takich jak Zagłada należy każdorazowo pytać o przekształcające znaczenie ludobójstwa, jego wpływ na społeczeństwo, kulturę i wszystkie ludzkie oraz pozaludzkie systemy. Trzeba też zastanowić się nad sposobami, a szczególnie językami kultury, ich „czystością” i „jednolitością” oraz miejscem w uznanych paradygmatach wiedzy. Interesujące wydaje się współwystępowanie wspomnianych języków w ramach określonej działalności artystycznej, spotkanie w określonym projekcie, przekraczanie go, translokacje, przechodzenie z jednej przestrzeni tradycji do innej, przenikanie się wspomnianych języków i granic 3 . Twórczość Rosenstein stanowi doskonałą okazję nie tylko, by ponawiać te wiele razy stawiane w przeszłości pytania, ale także by obserwować reakcje artystów na Zagładę sprzyjające wypracowywaniu różnych strategii konwersacyjnych zapośredniczonych w doświadczeniach typowych dla Europy Środkowej. Jedną z nich może być zjawisko określane jako przekład intersemiotyczny. Nazywa się w ten sposób „transpozycję z jednego systemu znaków (semów) do innego" (Kaźmierczak 2017: 30), najczęściej przedstawianą jako ilustrowanie muzyką literatury lub literaturą muzyki, obrazowanie za pośrednictwem prozy, poezji bądź dramatu dzieł malarskich i odwrotnie odmalowywanie literatury etc. Warunkiem przekładu intersemiotycznego staje się transformacja tego samego zjawiska, tematu czy problemu do innej rzeczywistości znakowej, przy czym zakłada się, że muzyka, malarstwo, film, literatura (tak jak i inne typy działalności artystycznej człowieka) tworzą odrębne systemy, nieinterferujące ze sobą. Podkreśla to także Roman Jakobson, gdy pisze o autonomii i nieprzekładalności poezji:

Gra słów czy - posługując się bardziej uczonym i może bardziej precyzyjnym terminem - paronomazja króluje w sztuce poetyckiej i bez względu na to, czy jej panowanie jest ograniczone, czy nie, poezja jest nieprzetłumaczalna ex definitione. Możliwa jest tylko twórcza transpozycja wewnątrzjęzykowa - z jednego kształtu poetyckiego na inny, albo wreszcie transpozycja międzysemiotyczna $-\mathrm{z}$ jednego systemu znaków na inny, tj. ze sztuki słowa na muzykę, taniec, film czy malarstwo (Jakobson 1989: 380-381).

3 Szczególnie ważne wydaje się rozróżnienie przenikania się różnych rodzajów sztuk w obrębie twórczości jednego artysty (jak Rosenstein, Bracha L. Ettinger czy Ewa Kuryluk) od interferencji zachodzącej między dziełami różnych autorów. O tym drugim przypadku pisze wyczerpująco Adam Dziadek (2004). 
Do wniosków Jakobsona odwołuje się Edward Balcerzan w swojej definicji transmutacji (tłumaczenia intersemiotycznego), pisząc, że przy okazji przekładu dochodzi do utraty specyficznych właściwości dzieła w obrębie jednego systemu i „odzyskania” ich w innym (Balcerzan 1982: 142). Słowo „mutacja” na tle pojęć takich jak transpozycja czy translacja cechuje się dużym potencjałem zmiany, oznacza bowiem „rekonstrukcję dzieła sztuki” (Balcerzan 1982: 150), będącego nie strukturą statyczną, ale strukturą „dynamiczną, ewoluującą w historii” (Balcerzan 1982: 150). Analizując pracę Po końcu sztuki Arthura C. Danto, Agata Stankowska zwróciła uwagę na wpływ Zagłady na dezaktualizację takich zjawisk jak „czystość sztuki”, a w dalszej kolejności - na przyczynienie się Zagłady do poszukiwania „dróg wyjścia z konstruktywistycznych praktyk” (Stankowska 2019: 33) w kierunku kontynuacji surrealizmu i taszyzmu. Konsekwencje Holokaustu dla sztuki okazały się więc groźne przede wszystkim dla projektów opartych na trwałych fundamentach ${ }^{4}$. Jeśli by przekład intersemiotyczny traktować jako jeden $\mathrm{z}$ takich projektów, to należałoby wnieść do jego definicji korektę lub w ogóle zrezygnować ze stosowania wspomnianego pojęcia do opisu tego typu zjawisk. Pisał o tym Adam Dziadek, tłumacząc, że „związków pomiędzy obrazami i tekstami literackimi nie da się już [...] zamknąć w nieco sztywnej, podporządkowanej prymatowi semiotyki, formule Jurija Łotmana, który zaliczał malarstwo i muzykę do tzw. wtórnych systemów modelujących" (Dziadek 2004: 14). O wiele wygodniejszą propozycję dla badań nad relacjami między sztuką i literaturą, wydobywającą przede wszystkim ich wzajemne wpływy, zaproponował wspominany przez Stankowską William J. Thomas Mitchell. Autor Zwrotu piktorialnego dostrzegł podobieństwo widzenia i czytania, ale też złożoność obu procesów. W dalszej kolejności oddzielił je od siebie, tłumacząc, że nie sposób analizować widzialnego stosując model tekstualności (Mitchell, Thomas 2009: 15). W późniejszej o kilka lat pracy Mitchell uznał konieczność zestawiania obu kategorii, przyznając ostatecznie, że wszystkie media są mieszane, nie istnieje „czystość sztuki” (Stankowska 2019: 15), a literatura „włącza wirtualne lub imaginacyjne doświadczenie przestrzeni lub widzenia, które są nie mniej realne, mimo że zapośredniczone przez język" (Stankowska 2019: 34-35).

Według Barbie Zelizer związek między słowem i obrazem staje się bardziej złożony w przypadku pamięci zbiorowej. Podczas gdy słowa mogą być kartami z katalogów czy sprawozdaniami pomocnymi w procesach sądowych, należącymi do czegoś w rodzaju „banków pamięci” (Zelizer 1998: 6), o tyle obrazy

4 Nie był takim projektem na pewno surrealizm, chociaż Agata Stankowska, wskazując na powojenną „niemożność awangardy”, pisała nie tylko o komercjalizacji, ale też o nadmiernej estetyzacji jej dziedzictwa (Stankowska 2007: 184). 
zależą przede wszystkim od swojej materialnej formy, pełniącej funkcję memorialnego wehikułu. „Pamięć o przeszłości ułatwiają [facilitated] zdjęcia, obrazy czy urywki filmów obecne w sferze publicznej” (Zelizer 1998: 6). Trzeba wszelako zdawać sobie sprawę, że należące do pamięci zbiorowej obrazy są najczęściej konwencjonalne i proste w przeciwieństwie do obrazów przechowywanych w pamięci indywidualnej. Różnicę tę uzmysławiają asamblaże, rysunki, obrazy, opowiadania i wiersze Rosenstein, tworzone przeciwko skonwencjonalizowaniu pamięci zbiorowej i powszechnym wzorcom pamiętania. Artystka, prezentując wyniki pracy z negatywami zdjęć rodzinnych, począwszy od lat siedemdziesiątych, starała się przekonać, że pozagładowe strategie konwersacyjne wymagają równoczesnej mobilizacji sił na wielu różnych poziomach i nie tylko przeformułowania tradycyjnych pojęć, ale też zmiany podejścia do najstarszych ludzkich aktywności, takich jak pisanie i rysowanie. Jak przekonywał Jack Goody:

Pismo umożliwiło rozwój pojęć, sformalizowanie ich aż po stworzenie logiki i logików, logiki arystotelesowskiej, sylogizmu, który w pewnym sensie jest formalizacją rozumowania sekwencyjnego [...]. Pismo bowiem wspomaga ten sposób myślenia, podobnie jak i ono, jak sądzę, doprowadziło do terminologicznego sformalizowania sporu ikonoklastów ze zwolennikami kultu obrazów (Goody 2012: 140-141).

Dlatego też działania Rosenstein, nawet jeśli przypominają przekład intersemiotyczny, to nim nie są, zbliżają się natomiast do tego, co van Alphen nazywa traumatycznym przywróceniem, a Bracha L. Ettinger określa mianem transkryptum.

W 1976 roku artystka wykonała niewielki rysunek tuszem na papierze zatytułowany $M \dot{z} y$. Miniaturę o wymiarach 10,5 $\times 14 \mathrm{~cm}$ podpisała w lewym dolnym rogu sygnaturą „E. Rosenstein”. Podpis został wykonany tą samą techniką co splot kropek i kresek umieszczony na środku kartki. Można go porównać do nieporadnej próby zakreślenia lub zakrycia czegoś, bazgroty, ale też do płonących polan, z których sypią się iskry, ogniska, gorejącego krzaku. Jest to jednak skojarzenie ryzykowne, a nawet niezgodne $\mathrm{z}$ intencją autorki, która nadając dziełu taki tytuł, chciała wskazać na jego związek z wodą i wilgocią. Jak podaje Słownik języka polskiego, wyraz „mży” oznacza „1. o deszczu: padać gęsto drobniutkimi kroplami, 2. świecić słabym światłem" (Drabik i in., red. 2009: 468). Rysunek może więc odnosić się zarówno do niepogody, jak i do słonecznego dnia, a nawet słońca, a więc obejmować różne doświadczenia zmysłowe $\mathrm{z}$ widzialnością włącznie. Dwa lata później Rosenstein napisała wiersz zatytułowany dokładnie tak samo jak wspomniany rysunek: 
Jak czerpać z tego samego garnka snu, kiedy dłonie mam spowite ciepłem, a nogi w głębi?

On jest prawie tu...

1978

(Mży, wś, 58)

Narracyjny, tajemniczy czterowers nie jest wiernym przekładem intersemiotycznym rysunku. W ogóle trudno w tym przypadku mówić o przekładzie jednego systemu znaków na inny. Można wiersz Mży czytać jako uzupełnienie dzieła sztuki lub też jako całkowicie osobny głos, który w kilku, trudnych do wskazania, miejscach spotyka się z rysunkiem. Ich związek - prawie niemożliwy do weryfikacji za pomocą tradycyjnych narzędzi takich jak wspomniany przekład intersemiotyczny - wymaga oddzielnej analizy. Należy w niej uwzględnić fakt, że wiersz został włączony do autorskiego zbioru Wszystkie ścieżki (wiersze wybrane) opublikowanego przez Wydawnictwo Literackie w 1978 roku wraz ze stu dwudziestoma sześcioma innymi wierszami ${ }^{6}$. Książka składa się z dwunastu części zatytułowanych za pomocą zwięzłych, eliptycznych wypowiedzi lub pojedynczych słów zakończonych wielokropkiem: Mówić..., Sprawom bezimiennym..., Wszyscy jesteśmy tylko obok..., Przestrzenie..., Za brama... poza..., Noc..., Czas spoza czasu..., Niewygasłe..., Pomnik tym, którzy nie mówią..., Obecność..., Mieszkać..., Urodziłam się... umrę... Większość wierszy nie jest bezpośrednią odpowiedzią na jakiekolwiek dzieło malarskie, natomiast interferuje („współdziała”, „współgra”) z pięcioma rysunkami tuszem powstałymi w połowie lat siedemdziesiątych, które poetka zamieściła w książce. Składają się one z wyraźnych, długich kresek ułożonych w niestabilne figury przypominające zarysowywanie czy zakreślanie czegoś. Odpowiada temu wiersz Przekreślenia:

\author{
Ołówek - długi nóż \\ do takiego pisania, żeby przekłuć serce. \\ Papier - pusty śnieg \\ Do takiego milczenia, żeby nikt nie słyszał.
}

5 Wiersze z tomu Erny Rosenstein Wszystkie ścieżki cytuję za wydaniem: Rosenstein 1978. Po cytacie podaję tytuł utworu, skrót „wś” oraz numer strony.

6 Inne zbiory wierszy poetki, jak Ślad (1972), Spoza granic mowy (1976) czy Czas (1986), nie zawierają rysunków. Zawiera je natomiast obszerny wybór niepublikowanych wcześniej wierszy poetki i rozmów z nią przygotowany przez Zbigniewa Taranienkę Erna Rosenstein. Rzeczy, ślady, papiery z szafy (Taranienko, oprac. 2002). 
Dzień -

- do chodzenia, chodzenia, żeby go ZADEPTAĆ.

1977

(Przekreślenia, wś, 15)

Przykładem graficznej krypty (łac. crypta z gr. krypté ‘kryjówka’; w ogólnym znaczeniu - ukrywanie czegoś, zacieranie, zakreślanie) może być rysunek umieszczony obok wiersza Bańka mydlana z 1975 roku, przedstawiający prawdopodobnie postać kobiecą w sukni osłoniętą gęstą siecią kresek uniemożliwiających odróżnienie jej od tła. Niektóre ilustracje wydają się bardziej staranne i przypominają krążące w nieokreślonej przestrzeni, postrzępione obiekty, inne nie są w ogóle uporządkowane i tworzą zbiorowisko pozornie przypadkowych znaków. Rosenstein nawiązuje w swoim dziele prawdopodobnie do dziecięcej bazgroty. Jest to naturalny etap rozwoju umiejętności graficznych dziecka, przypadający na pierwsze pięć lat jego życia. Według Rhody Kellogg używa ono podczas rysowania m.in. kropek, linii prostych wertykalnych, linii prostych horyzontalnych, ukośnych etc. (Szuścik 2019: 15). Bazgrota jest przejawem swobody twórczej i wolności, jednak „zakonserwowana” w sztuce dorosłych artystów może także przypominać o jej związkach ze smarowaniem (np. kałem) (Szuścik 2019: 35), techniką, do której z kolei nawiązywał taszyzm. Stankowska łączy ten kierunek, za Danto, z naruszaniem „czystości” w malarstwie i odejściem od konceptu „sztuki czystej” (Stankowska 2019: 33).

„Nabazgrany” wiersz Mży z rysunkiem o tym samym tytule spotyka się zatem nie w książce, ale w przestrzeni podobnego języka graficznego, przypominającego zabawy dziecka, które nie odróżnia pisania od rysowania. Głęboko ukrytym, „kryptualnym” tematem tego utworu, podobnie jak wielu innych wierszy z Wszystkich ścieżek, wydaje się utrata rodziców, a zwłaszcza matki. Jest to jednak temat zakryty fasadą znaków graficznych, niejednoznacznie opowiedzianych historii, labilności podmiotu czy wirujących, nierealistycznych zdarzeń. Żadne konkretne wskaźniki nie pozwalają dowieść, że śmierć rodziców stanowi w tym przypadku oś poetyckich zdarzeń. W odniesieniu do rysunków pisała o tym Jarecka, zwracając uwagę, że ukrywanie nie stanowi najważniejszego celu artystki. Jest nim układanie na powrót rozproszonych, zdekonstruowanych wizerunków rodziców, a zwłaszcza portretów ich twarzy:

Rysunki to ćwiczenia na siłę magiczną kreski i kropki. Kojarzą się z momentem, w którym substancje chemiczne wywołują obraz na kliszy. Mając w pamięci moment odnalezienia klisz w zakładzie fotograficznym w Krakowie, można zaryzykować tezę, że każdy rysunek 
jest powtórzeniem procesu wywoływania tamtych zdjęć. Ich kontrast, ziarno, barwa to tyko kwestia dostępnych środków technicznych. Nawet źle wywołany obraz już jest wystarczającym dowodem, że rodzice tam są. To jakby próba stworzenia fotografii siłami natury, takiego wpatrzenia w kropki i kreski na papierze, że w końcu postać sama się wyświetli (Jarecka, Piwowarska 2014: 90-91).

Kluczowe wydaje się tu zwłaszcza słowo „portret”. Wprawdzie żaden z wierszy nie dotyczy wprost portretu, jednak jeśli przyjąć, że większość z nich7 powstała pod wpływem rysunków rodziców wykonanych tuszem, które z kolei zainspirowały odnalezione zdjęcia, można zobaczyć w dziełach Rosenstein z tego okresu, i to zarówno tych z książki Wszystkie ścieżki, jak i tych niewłączonych do niej, sztukę transkryptualną, czyli taką, która źródłem swojej myśli czyni czyjąś traumę i z niej czerpie inspiracje. Pojęciem „sztuka transkryptualna” w odniesieniu do prac Rosenstein posłużyłam się już wcześniej (Tomczok 2019: 204-208), zestawiając wybrane wątki poezji i malarstwa artystki z teorią macierzy Ettinger. Sztuka okazuje się w tym kontekście strukturą dynamiczną (transmutacja), pozostającą w nieustannym ruchu: przepływ doznań i doświadczeń (grawerunków) odbywa się między wieloma podmiotami, osiada jednak na i w rzeczach, czyniąc je wizualnymi śladami jakiejś historii, ponawianej wciąż od nowa i od nowa. Jej prawzorem jest archaiczne i nieodżałowane doświadczenie relacji z matką, które w dorosłym życiu podmiot zamyka w krypcie (zatrzaskując - jak w wierszu Papier - wieko):

[...] krypta może być przekazana przez jeden podmiot innemu poprzez metamorfozę, ponieważ możliwość i okazja ku takiemu przekazowi, ku współ-afektywności, współ-działaniu i współ-tworzeniu zdarzyła się już w archaicznym związku pomiędzy każdym ze stających się podmiotów oraz matką-Innym (Ettinger 2016: 106).

Doświadczenie to u Rosenstein przybiera wymiar historii osobistej, osadzonej jak gdyby na matrycy z okresu niemowlęcego (i okresów wcześniejszych), łączy się też z ludobójstwem, przez co wymaga działań odzyskujących i pielęgnujących pamięć, ocalających i przeciwdziałających zapomnieniu. Transkryptum

7 Zupełnie inną problematykę podejmują wiersze należące do grupy tekstów „marcowych” (tematycznie związanych z Marcem 1968) i „zwierzęcych” (związanych ze śmiercią zwierząt domowych: Kotka, Uśpiłam cię..., Pies łańcuchowy). Wiele z nich - za sprawą melancholijnego nastroju, elegijności, tonacji żałobnej - odsyła do tamtej straty. 
jest zatem w dziele Rosenstein miejscem pochówku i ukrywania dwu strat: odwiecznej utraty matki przez córkę, wpisanej w historię gatunku ludzkiego, i zabicia matki, którego świadkiem była córka - w lesie, nocą 1942 roku. Ta druga historia, opowiedziana wiele lat później, wydaje się awersem czy może raczej wariantem mitu o Demeter i Korze, uchodzącego za opowieść o nieusuwalnej i niezrozumiałej stracie, strącającej kobiece pragnienia i doznania do podziemi. Nawiązuje do niego Rosenstein w wierszu Siostro moja:

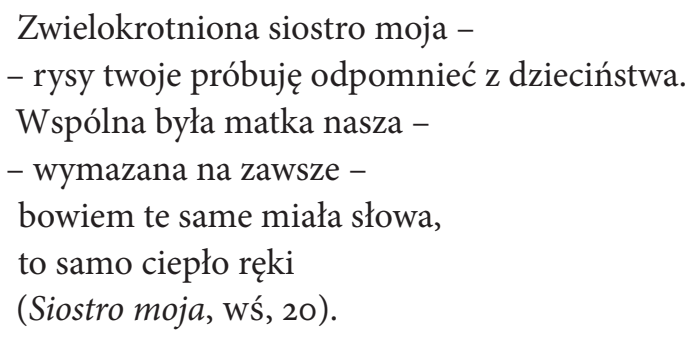

Według Adrienne Rich fundamentalnym doświadczeniem naszej cywilizacji jest podwójna utrata: matki przez córkę i córki przez matkę ${ }^{8}$ Została ona jednak zapomniana przez kulturę, pamięta się natomiast o tragediach męskich: króla Leara, Edypa, Hamleta. Ostatni zbiorowy przejaw pamięci o tej stracie stanowią misteria Elezuzis: „rytuał ten był najbardziej zakazany i objęty największą tajemnicą klasycznej cywilizacji, nigdy nie odgrywany na scenie, dostępny tylko dla wtajemniczonych, którzy wcześniej przeszli długi proces oczyszczenia” (Rich 2000: 326). Jego odnowienie wymaga od kobiet pogrążenia się w (symbolicznej) ciemności i ciszy oraz porzucenia porządku patriarchalnego, co odcina im dostęp do najróżniejszych kodów kultury: „Tylko silna swą symboliką kobieta może wystąpić przeciwko wszechobecności męskiego imaginarium" (Araszkiewicz 2001: 674). W twórczości Rosenstein wraz z ideą transkryptum - krążących za pośrednictwem rysunku i poezji afektów - ożywa

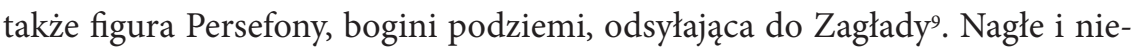
spodziewane rozdzielenie matki z córką, opisane przez poetkę, upodabnia to zdarzenie do tysięcy makabrycznych rozstań rodziców i dzieci w czasie wojny; niewytłumaczalna rozpacz i nieukojona tęsknota rozdzielonej rodziny z mitu ma wiele cech wspólnych z rozpaczą innych rodzin żydowskich; wreszcie

8 Częściowo temat ten podjęła w obszernej, bogatej w przykłady, poświęconej prawie wyłącznie literaturze po 1989 roku monografii Matki i córki. Relacje rodzinne i artystyczne $w$ autobiografiach kobiet po 1989 roku Aleksandra Grzemska (2020).

9 Znakomitym, choć późniejszym o wiele lat przykładem nawiązania narracji pozagładowej do historii Persefony jest Utwór o Matce i Ojczyźnie Bożeny Keff (2008). 
z Zagładą łączy ów mit, a szczególnie misteria eleuzyjskie, podwójny wymiar śmierci: krwawej i ofiarniczej, a następnie przekształcającej tragedię w wieczne życie bogów i roślin, w zoe (Kerényi 2004: 188-189).

Z roślinnością wiąże się też tytuł książki poetyckiej Rosenstein. Wszystkie ścieżki są prawdopodobnie reminiscencją tytułowej metafory z opowiadania Jorge Louisa Borgesa Ogród o rozwidlających się ścieżkach. Ścieżkami są tam narracje umożliwiające bohaterom i czytelnikom poruszanie się we wszystkich czasach i przestrzeniach równocześnie, narracje totalne, powieści umożliwiające lekturę we wszystkich kierunkach naraz (Borges 2019: 101). W przypadku zbioru Rosenstein rośliny mają bardziej rzeczywisty status. Już na samej okładce (rysunek z 1978 roku sygnowany „E.R.”) pojawiają się elementy zoe, przypominające proste organizmy jednokomórkowe, widziane przez mikroskop. Wyrastają z nich pojedyncze nitki, być może odnóża, zaś kropki wewnątrz tych przedziwnych pierwotniaków tworzą wrażenie oka. Każdy z nich znajduje się jak gdyby $\mathrm{w}$ kokonie narysowanym $\mathrm{z}$ linii prostych i załamujących się, co tworzy - podobnie jak w przypadku wierszy - iluzję koncentrycznie usytuowanych istnień, znajdujących się jedno w drugim. Podłożem tej iluzji zdaje się być idea transkryptum, której Rosenstein nadaje rys indywidualny, łącząc ją z prawdziwym zabójstwem matki i wiekuistym strąceniem córki do podziemi. Narusza to nie tylko odwieczny rytm życia i śmierci, wynikający z rozstań matki i córki oraz ich ponownych spotkań. Ostateczne rozejście się tych dwu istnień, na zawsze powiązanych ze sobą, ingeruje w fundament ludzkiego bytu, w jego - jak pisze Karl Kerényi - żeńskie źródło życia (Kerényi 2004: 192). Uwagi węgierskiego filologa w ogólnym zarysie przypominają także koncept Ettinger:

Wizja eleuzyjska musiała mieć moc, przed której uznaniem filozofowie wzdragali się. Przede wszystkim powoływała się na prawdę, którą rozpoznawały dusze epoptów. Nie negowała dwoistości szukającego i znalezionego. Dwoistość ta - rozszczepienie Matki na „matkę i córkę” otwierała wizję żeńskiego źródła życia, wspólnego źródła życia dla mężczyzn i kobiet zarówno, tak jak kłos zboża otwierał wizję „otchłani nasienia”. Bierze się to prawdopodobnie stąd, że wszystkie istoty ludzkie, nie tylko kobiety, noszą ten początek, tę dwoistość - która jest zarówno Matką, jak i Córką - w samych sobie, w tej mierze są więc dziedzicami nieskończonego następstwa, nie tylko ojców, lecz także matek (Kerényi 2004: 192-193).

Bohaterką Wszystkich ścieżek jest dziedziczka spadku po matce, mistrzyni paradoksów, żyjąca równocześnie w kilku czasach i przestrzeniach, sprawcza i wycofana, samotna i wypowiadająca się z dna trudnego doświadczenia, z otchłani: 
Zszywam żyletki.

Zaklejam noże.

Wodę zawijam w ogień

I piekę chleb powszedni z milczenia

(Jak?, wś, 7).

Otchłań to podziemie, świat zmarłych, dokąd ta, która mówi, została wciągnięta przez nieznane siły:

Rzuciłam klucz na samo dno ognia.

Topielcy pukają o popiół.

Dzwonią na ciemność i na jawę.

Jestem odtąd poślubiona dnu [wyróż. - M.T.]

Idę dół odchylić [...]

Ja rzuciłam na samo dno ognia klucz.

Niczego otworzyć nie mogę.

Nikt mi nawet nie pokaże,

jak odchylić...

1970

(Od tego czasu, wś, 13o)

Metafora „poślubiona dnu” zdaje się odsyłać do mitu o Demeter i Korze. Aretuza, nimfa Awernu, bohaterka Przemian Owidiusza, tak mówi o losie porwanej dziewczyny:

Gdy Styksem wśród podziemnej przepływałam jazdy,

Dojrzałam własnym okiem twojej Prozerpiny.

Jest smutną, lecz królową ponurej krainy,

Lecz błyszczącą w pieczarach najpierwszą koroną,

Lecz wszechmocną monarchy piekielnego żoną (Owidiusz 2002: 122).

Domyślna Prozerpina, a właściwie Persefona, z wierszy Rosenstein cały wysiłek wkłada w przywrócenie relacji z matką i ożywienie Demeter. Ponieważ wie, że nie są one możliwe, ryzykując brak porozumienia z otoczeniem, próbuje odtworzyć zerwaną więź za pomocą symboliki niemającej żadnej tradycji.

Dzieło sztuki - tłumaczy Ettinger - wzywa nas do namysłu nad zagadką pamięci transpodmiotowej i połączonej afektywności. Ja, podmiot 
niosący kryptę innych nie-Ja dla nich oraz w ich miejsce, [...] musi zbudować most do traumy w formie Rzeczy i Wydarzenia ukrytych za pierwotnym wyparciem... (Ettinger 2016: 105).

Ślady pamięci, o których dalej pisze Ettinger, służą inscenizacji traumy, a więc doświadczeniu Wydarzenia po raz kolejny, ale w formie dramatu przetwarzającego naoczne świadectwo. Prowadzą więc nie ku narracjom o Zagładzie, które van Alphen łączy ze sprawowaniem kontroli przez narratora lub narratorkę nad wspomnieniami, ale do traumatycznego przywrócenia. „Osoba przeżywająca traumatyczne przywrócenie tkwi we wnętrzu wydarzenia, jest w nim obecna. To tłumaczy, dlaczego traumatyczne przywrócenia narzucają się jako ślady wizualne [wyróż. - M.T.]" (van Alphen 2019: 86).

Rzadko Rosenstein portretuje żywą matkę. Wyjątkiem jest wiersz $\mathrm{Za}$ wcześnie, w którym zamiast pogodnej, uśmiechniętej twarzy, znanej z oleju na płótnie Północ (Portret matki) z 1979 roku, pojawia się „matka moja, żywa, / [która - M.T.] rozsnuwa po światłocieniach pajęczynę uśmiechów, / ciepło miodu” (Za wcześnie, wś, 131). Zazwyczaj artystka „pisze” matkę - jak należałoby powiedzieć, biorąc pod uwagę to, że jej rysunki są wykonane tuszem służącym też do pisania i w pewien sposób przypominają ikony ${ }^{10}$ - znacznie mniej wyraźnie, odwlekając w czasie ukończenie dzieła, zostawiając wspomnienie w kawałkach, chaotyczne, niescalone. Najczęściej powracający sposób portretowania ma na celu inkorporację matki, wchłonięcie ducha, wraz z zapamiętanymi obrazami, przez ciało córki, które rozsuwa swoje granice (borderspacing - Bojarska 2012: 152), stając się czymś w rodzaju transkryptualnego dybuka, nawiedzającego współczesną Persefonę:

Kiedy nic do ciebie nie mówię... mówię.

Kiedy nie patrzę na ciebie... widzę.

Jesteś za drzwiami... jesteś we mnie.

Bledniesz bardziej od powietrza... wyraźniejesz jak klisza

1977

(Tak jest, wś, 22).

10 Ze względu na liczne analogie między twórczością Rosenstein i pracami młodszej od niej o 33 lata Ewy Kuryluk warto przeanalizować ją, podobnie jak uczyniła to Stankowska w odniesieniu do Kuryluk, za pomocą pojęcia „obrazu prawdziwego” (acheiropoietoi), oznaczającego w tym przypadku zarówno obecność fundamentalnej problematyki poszukiwania prawdy w sztuce i jej tworzywie, jak i refleksję nad historią kobiet, kobiecymi mitami oraz fizjologią (Stankowska 2019: 199-234). 
W pozagładowej powieści kanadyjskiej pisarki Anne Michaels Fugitive Pieces $^{11}$, opublikowanej dwadzieścia lat po Wszystkich ścieżkach, pojawia się scena inkorporacji zabitej na oczach syna matki. Jej duch wnika w ciało syna i przebywa w nim tak długo, dopóki się z nim nie pożegna:

[...] nagle pojmuję, że moja matka jest we mnie. Że porusza się w moich ścięgnach, pod moją skórą w taki sposób, w jaki zwykle poruszała się w domu nocą, robiąc porządki. Zatrzymała się we mnie po to, by powiedzieć „żegnaj”, i teraz nie wie, co ma zrobić: zostać czy się unieść ku niebu (Michaels 2000: 13).

Relacja matki i córki w wierszu Tak jest opiera się na jeszcze wyraźniejszych paradoksach („nie mówię... mówię”, „nie patrzę [...] widzę”). Podmiot, próbując przywrócić matkę, odwołuje się przede wszystkim do doznań wzrokowych, ale i tu nie unika dwuznaczności. Wywołując klisze zdjęć z jej podobizną, jednocześnie przestaje dostrzegać matkę, jakby owo uwidacznianie rozpływało się w powietrzu. Prawdopodobnie jedynym sposobem na zatrzymanie matki jest użyczenie jej swojego ciała, owo Irigaray’ańskie „ciało-w-ciało z matką”; przedmioty takie jak klisze czy zdjęcia są w tym procesie jedynie niepotrzebnymi pośrednikami. Zawiązana na nowo relacja, która ma przezwyciężyć śmierć, wymaga odwagi i odwrócenia porządku biologicznego. Kiedyś dziecko znajdowało się w matce, połączone z nią łożyskiem i pępowiną. Dzisiaj to matka próbuje przedostać się przez jego skórę do wnętrza:

Jak mam wejść do ciebie przez skórę?

Dotknięcie jest z wierzchu tylko.

Oko wykąpie się w oku

i wróci...

1971

(Matka próbuje, wś, 26)

Zjawisko wzajemnego przenikania się organizmów żywych i umarłych pojawia się także w innych wierszach. W Przestrzeń jest we mnie podmiot mówi:

Jestem ojciec i matka.

Rozsypuję ich słowa.

11 A. Michaels, Fugitive Pieces, London 1998. W Polsce powieść ukazała się pod tytułem Płomyki pamięci (zob. Michaels 200o). 
Właściwie,

kiedy rozwieram wargi,

mówią oni sami.

A już

we wnętrzu, które na zewnątrz

samo NIC stwarza,

to istniejące - co jeszcze nie żyje -

- żyje ze mnie

1974

(Przestrzeń jest we mnie, wś, 10)

Myśli o przenikaniu się ciał żywych i umarłych towarzyszą rysunki włączone do zbioru, jak przypominający słup czy tatarak splot kilku pionowych kresek i punktów, pozostawiony bez sygnatury i daty, a umieszczony zaraz obok wiersza Tak jest (wś, 23). Te, zdawałoby się, skromne artystyczne gesty w rzeczywistości są zaplanowanym działaniem uwieczniania obrazów ulatujących z pamięci. O ile bowiem słowa rozpadają się, „kołyszą się litery pod prądem. One nie znaczą nic prócz znikania" (Papier, wś, 9), o tyle wykonane niezmywalnym tuszem rysunki zmierzają ku czemuś zgoła odwrotnemu, przy czym odzyskiwanie obrazu musi kosztować oko wysiłek. Jarecka o rysunkach tuszem Rosenstein pisała:

One same wypływają na powierzchnię, pojawiają się bez naszego udziału. Coś je przywołuje. Rysunek powstały w rezultacie takiego procesu jest rzeczywiście nie ręką ludzką stworzony, jak ów rysunek bez tytułu, który przypomina to, co w tradycji obrazów kulturowych określane jest jako veraikon (Jarecka, Piwowarska 2014: 91).

Uwaga badaczki odnosi się do niewielkiego, czarno-białego portretu matki $(10 \times 20,9 \mathrm{~cm})$. W lewej części kartki znajduje się jej drobna, pokreślona głowa, dość wyraźnie zakreskowana. Została ona „włożona” w sieć krzyżujących się kresek przypominających igły bądź ciernie, które tworzą gniazdo, a może macicę. Jeśli istniałaby potrzeba wizualizacji transkryptum, mógłby nią być właśnie ten niepozorny rysunek z 1997 roku przedstawiający opancerzoną, uzbrojoną macicę (córki?), w której znajduje się głowa matki, a właściwie pamięć o niej (pamięć o zdjęciach, portretach, obiekcie sztuki). Szczególnie ważne wydaje się, że traumatyczne przywrócenie, dokonujące się na tym rysunku, polega przede wszystkim na uwidacznianiu i niczym więcej. Jak mówiła artystka: 
Nieraz jak maluję, to mam wrażenie, że ja tylko uwidaczniam to, co i tak płynie w powietrzu [wyróż. - M.T.]. Pilnuję tylko, żeby się dobrze odbiło na płótnie, żeby było prawdziwe. Mam uczucie, że ja tylko próbuję uwidocznić coś, co i tak istnieje, albo coś co będzie, ale ja to mam już w sobie. Tam wewnątrz jest całkowite pomieszanie czasu i przestrzeni, tumult, chaos (Rozmowa Łukasza Guzka... 1992: 17-18).

W podobny sposób mówiła inna polsko-żydowska artystka i poetka, Krystiana Robb-Narbutt: „Jak patrzysz na jedną rzecz i ją kontemplujesz, to ona się robi wielka, mocna, ona cię nagle obejmuje, nabiera innego znaczenia, spróbuj, wiesz, na cokolwiek, tak pokontemplować, nie wiem, oczywiście ja bym kropkę mogła pokontemplować..." (Krystiana Robb-Narbutt, dostęp 2020). Należy przy tym pamiętać, że rysunki Rosenstein nie uwidaczniają sceny zabicia rodziców, nie ma w nich więc dosłownie Zagłady. Starają się przedstawiać przedwojenne portrety, przypominać twarze uwikłane w określoną konwencję, ale też - jak czyniła to Ettinger, powielając dziesiątki razy jedyne zdjęcie matki, które posiadała - dystansować się wobec aktu przypominania, czynić problemem prawdę twarzy, ukazywać jedynie to, co w bardzo ogólnym znaczeniu odebrała ludziom Zagłada. Zaufanie wobec „zakazanych fotografii”, jak dowiodła Stankowska, należy budować, przestrzegając dwu warunków:

Po pierwsze, że posługiwaniu się nimi towarzyszyć będzie gruntowna znajomość historii tych zdjęć, znaczona akrybią w identyfikacji źródeł, i pogłębiona wiedza o faktograficznym kontekście utrwalonych na kliszy wydarzeń. Po drugie, że w artystyczną formę wpisany immanentnie metakrytyczny namysł nad ograniczeniami właściwymi każdej konwencji. Tylko wówczas zarówno dokumentalne, jak i artystyczne fotografie rodzić będą w odbiorcy przymus postawienia pytań o status obrazowego przedstawienia i - równolegle - o rolę własnej pamięci i postawy wobec dwudziestowiecznych traum (Stankowska 2019: 262).

Sądzę, że w przypadku poezji i sztuki Rosenstein mechanizm nicujący konwencje artystyczne oraz testujący ich „dostosowanie” do możliwości i potrzeb upamiętniania osobistej traumy związanej z utratą rodziców, a w szerszym planie także z Zagładą, pochodzi z tradycji jedynie w pewien sposób związanej z przekładem intersemiotycznym - anamorfozy. Jest to optyczna sztuczka polegająca na „przestawianiu elementów i funkcji. Zamiast zmniejszać stopniowo formy do granic ich widzialności, rozszerza je, rzutuje poza nie same w taki sposób, że odtwarzają się one w określonym punkcie widzenia, rozbija je po to, 
by je odbudować, każe im znikać po to, by następnie powróciły" (Baltrušaitis 2009: 7). Łączona z fascynacją możliwościami widzenia i geometrii anamorfoza, której pierwsze przykłady powstały w Xv I i Xv II wieku (Ambasadorowie Hansa Holbeina z 1533 roku), budziła też zainteresowanie surrealistów, w tym Jeana Cocteau, który, podobnie jak Rosenstein w przypadku tuszu, łączył fenomen iluzji optycznej z pismem i atramentem:

Poezja może zadomowić się (w społeczeństwie), zanim stanie się doświadczeniem niebezpiecznym, tylko w postaci zastygającego źródła, gdyż atrament poety posiada ów osobliwy dar petryfikowania pustki, zmieniania abstrakcji w przedmiot, nagłego przenoszenia $\mathrm{z}$ mroku w jasność, jednym słowem: ustawiania na anamorfozie tuby (lub, by wyrazić się bardziej potocznie: rury), wlewania w nas wiedzy o nieznanym (Baltrušaitis 2009: 264).

Utwory poetyckie z Wszystkich ścieżek, tak jak dołączone do tomu rysunki, stworzone są nie tylko ze słów, ale także ze znaków interpunkcyjnych, a zwłaszcza z wielokropków. System kropek i kresek, który powinien odnosić się albo do rysowania, albo do pisania, tutaj - niczym anamorfoza - staje się narracją „domyślną”, zmuszającą czytelnika, by wytężył oko i umysł i dojrzał w konstrukcjach graficzno-poetyckich ukryte znaczenia. Jean-Claude Margolin zauważył, że anamorfozy literackie charakteryzują kondensacje, odchylenia, skróty (Baltrušaitis 2009: 260). Są to anamorfotyczne ślady realnego, za pomocą których Rosenstein nie tylko stwarza określoną rzeczywistość, ale zakrzywia ją do tego stopnia, że bez gruntownej znajomości źródeł tych konceptów, do których jak wskazuje Stankowska - należą zarówno źródła historyczne, jak i biografia artystyczna, nie sposób rozstrzygnąć, co tak naprawdę jest obiektem namysłu poetki. Jak chociażby w wierszu Rozmowa: jego adresatką zdaje się być matka, bardziej niż gdziekolwiek indziej podobna do Demeter. Patrzy ona „tysiącem kwiatów”, jest zielona, dotyka córkę za pośrednictwem wiatru, łąki i milczenia. Wydaje się także rośliną - jak organizmy żywe z okładki Wszystkich ścieżek: jej ramiona obsiadły pszczoły i bąki, a z ciała wyrastają „kosmate narośla”. W tekście nie pada jednak ani razu słowo „matka”, można więc powiedzieć, że historia jej śmierci została tu jak gdyby „pogrążona”, utopiona, zniknęła. Widać ją jedynie „od środka”, z wnętrza obrazu i podmiotu („Stawiam kroki przez twoje ciało i krew”). Rosenstein kontynuuje w ten sposób, być może, metodę Władysława Strzemińskiego, zastosowaną w komentarzach do rysunków wojennych z cyklu Pamięci przyjaciół - Żydów. Tworzące je pojedyncze słowa, wielokropki, urwane zdania można traktować jak „językowy ślad” (Nader 2018: 350) świadectwa. 
Próbując nadać mu ramy skonwencjonalizowanego portretu, poetka stara się zachować tradycję malowania i uobecniania twarzy i jednocześnie czyni ów „Sztukobiekt” czymś rozmytym i nieoczywistym. Mnogość sprzecznych gestów, towarzyszących jej działaniom, odpowiada prawdopodobnie niepewności zrodzonej w artystce nie tylko przez jej osobiste doświadczenia, ale też przez możliwe urzeczywistnienie projektowanej transkrypcji, czyli życia z duchem „ciało-w-ciało”.

Twórczość Erny Rosenstein skłania do zmiany myślenia o relacjach między poezją a sztuką. Przekład intersemiotyczny wydaje się w jej przypadku pojęciem, które trudno byłoby zastosować z pożytkiem dla rozumienia tej twórczości i myślenia o niej. Rosenstein rezygnuje z wyodrębniania systemów znakowych oraz autonomizacji poezji i w miejsce sztywnych granic proponuje rozwiązanie zbliżone do łączenia (borderlinking) oraz rozsuwania (borderspacing) różnych systemów myślowych. W jej działaniu nad kategorią inter- dominuje kategoria trans-, pozwalająca swobodnie poruszać się różnym wspomnieniom, afektom, mitom czy skojarzeniom wewnątrz niesprecyzowanej struktury wiersza bądź obrazu połączonym - co widać szczególnie we Wszystkich ścieżkach - za pomocą znaków graficznych (jak kreski i kropki wykonane tuszem), rozwiązań edytorskich (sąsiadowanie pisma i rysunku, zlewanie się ich w jeden sztukobiekt), a przede wszystkim pewnych idei. Najważniejsza z nich wydaje się kategoria obrazu, opisywana przez poetkę niekiedy także jako „uwidocznienie”. Sztuka funkcjonuje tu jedynie na prawach medium, za pomocą którego pokazuje niewidoczne, formuje powietrze, pozwala się wypowiedzieć głosom ze środka, duchom. Ów przepływ, jakże daleki od istoty przekładu intersemiotycznego, odbywa się nie tylko między rysunkami a wierszami, lecz także między artystką a czytelnikiem, ich wzajemnymi wrażliwościami, pamięciami, traumami, ciałami. Transkryptualność nie jest jednak zjawiskiem niedefiniowalnym czy totalnym, jak mogłoby się wydawać, a jedynie opcją rozszerzenia pola rozumienia wspólnych interesów sztuki i wiersza. Stanowi ono, co starałam się pokazać, znacznie więcej niż doświadczenie wynikające z Zagłady. To ciemne źródło każdego jednego życia.

\section{| Bibliografia}

van Alphen Ernst (2019), Krytyka jako interwencja. Sztuka, pamięć, afekt, red. Katarzyna Bojarska, przeł. Katarzyna Bojarska i in., Wydawnictwo Uniwersytetu Jagiellońskiego, Kraków. 
Araszkiewicz Agata (2001), Czarny ląd czarnego kontynentu. Relacja matka córka w ujęciu Luce Irigaray, w: Ciało, płeć, literatura. Prace ofiarowane Profesorowi Germanowi Ritzowi w pięćdziesiąta rocznice urodzin, red. Magdalena Hornung, Marcin Jędrzejczak, Tadeusz Korsak, Państwowe Wydawnictwo Wiedza Powszechna, Warszawa, s. 671-705.

Balcerzan Edward (1982), Poezja jako semiotyka sztuki, w: tenże, Kręgi wtajemniczenia, Wydawnictwo Literackie, Kraków, s. 135-156.

Baltrušaitis Jurgis (2009), Anamorfozy albo Thaumaturgus opticus, przeł. Tomasz Stróżyński, słowo/obraz terytoria, Gdańsk.

Bojarska Katarzyna (2012), Robb-Narbutt - spotkanie z resztkami. Krystiana Robb-Narbutt, w: Rysunki, przedmioty, pracownia, red. Dorota Jarecka, Wanda Siedlecka, Fundacja im. Krystiany Robb-Narbutt, Warszawa, s. $145-159$.

Borges Jorge Luis (2019), Ogród o rozwidlających się ścieżkach, w: Fikcje, przeł. Andrzej Sobol-Jurczykowski, Stanisław Zembrzuski, Państwowy Instytut Wydawniczy, Warszawa, s. 91-105.

Drabik Lidia i in., oprac. (2009), Słownik języka polskiego, Wydawnictwo Naukowe PWN, Warszawa.

Dziadek Adam (2004), Obrazy i wiersze. Z zagadnień interferencji sztuk w polskiej poezji współczesnej, Wydawnictwo Uniwersytetu Śląskiego, Katowice.

Ettinger Bracha L. (2016), Transkryptum: tropienie śladów pamięci z/w/z myśla o Innym, przeł. Anna Chromik, Anna Kisiel, „Narracje o Zagładzie”, nr 2, s. $103-114$.

Hirsch Marianne (2010), Żałoba i postpamięć, przeł. Katarzyna Bojarska, w: Teoria wiedzy o przeszłości na tle współczesne humanistyki. Antologia, red. Ewa Domańska, Wydawnictwo Poznańskie, Poznań, s. 247-28o.

Goody Jack (2012), Człowiek, pismo, śmierć. Rozmowy z Pierrem-Emmanuelem Dauzat, przeł. Agnieszka Karpowicz, Wydawnictwo Uniwersytetu Warszawskiego, Warszawa.

Grzemska Aleksandra (2020), Matki i córki. Relacje rodzinne i artystyczne w autobiografiach kobiet po 1989 roku, Wydawnictwo Naukowe Uniwersytetu Mikołaja Kopernika, Toruń.

Jakobson Roman (1989), O językoznawczych aspektach przekładu, w: tenże, W poszukiwaniu istoty języka, t. 1. Wybór pism, wybór, red. nauk., wstęp Maria Reneta Mayenowa, Państwowy Instytut Wydawniczy, Warszawa, s. 372-381.

Jarecka Dorota, Piwowarska Barbara (2014), Erna Rosenstein. Moge powtarzać tylko nieświadome / I can repeat only unconsciously, Fundacja Galerii Foksal, Warszawa.

Juchniewicz Andrzej (2019), „Ziemia otworzy usta”. O wyobraźni forensycznej Erny Rosenstein, „Narracje o Zagładzie”, nr 5, s. 149-175. 
Kaźmierczak Marta (2017), Od przekładu intersemiotycznego do intersemiotycznych aspektów tłumaczenia, „Przekładaniec”, nr 34, s. 7-35.

Keff Bożena (2008), Utwór o Matce i Ojczyźnie, korporacja ha!art, Kraków.

Kerényi Karl (2004), Eleusis. Archetypowy obraz matki i córki, Wydawnictwo Homini, Kraków.

Krystiana Robb-Narbutt, rozmawia Ewa Stawecka, https://tinyurl.com/3h5ae2av [dostęp: 13.09.2020].

Michaels Anna (2000), Płomyki pamięci, przeł. Bogumiła Malarecka, Dom Wydawniczy Rebis, Poznań.

Mitchell William, John Thomas (2009), Zwrot piktorialny, „Kultura popularna”, nr 1(23), s. 4-19.

Nader Luiza (2018), Afekt Strzemińskiego. „Teoria widzenia”, rysunki wojenne, „Pamięci przyjaciół - Żydów”, Instytut Badań Literackich PAN, Warszawa.

Owidiusz (2002), Przemiany (Metamorfozy), przeł. Bruno Kiciński, Wydawnictwo Zielona Sowa, Kraków.

Rich Adrienne (200o), Zrodzone z kobiety. Macierzyństwo jako doświadczenie i instytucja, przeł. Joanna Mizielińska, Wydawnictwo Sic!, Warszawa.

Rosenstein Erna (1978), Wszystkie ścieżki, Wydawnictwo Literackie, Kraków.

„Rozmowa Łukasza Guzka z Erną Rosenstein” (1992), w: Erna Rosenstein, red. Józef Chrobak, Stowarzyszenie Artystyczne Grupa Krakowska, Kraków.

Stankowska Agata (2007), Poezji nie pisze się bezkarnie. Z teorii i historii tropu poetyckiego, Wydawnictwo UAM, Poznań.

Stankowska Agata (2019), Ikona i trauma. Pytania o „obraz prawdziwy” w liryce i sztuce polskiej drugiej połowy xx wieku, Universitas, Kraków.

Szuścik Urszula (2019), Bazgrota w twórczości dziecka, Wydawnictwo Uniwersytetu Śląskiego, Katowice.

Taranienko Zbigniew, oprac. (2002), Erna Rosenstein. Rzeczy, ślady, papiery z szafy, Galeria 86, Łódź.

Tomczok Marta (2019), Czy Polacy i Żydzi nienawidza się nawzajem? Literatura jako mediacja, Wydawnictwo Uniwersytetu Łódzkiego, Łódź.

Zelizer Barbie (1998), Remembering to forget. Holocaust memory through the camera's eye, The University of Chicago Press, Chicago and London. 


\section{| Abstrakt \\ MARTA TOMCZOK \\ Od inter- do trans-: ciemne źródła sztuki Erny Rosenstein}

W artykule przebadano operacyjność pojęcia przekładu intersemiotycznego w poezji pozagładowej Erny Rosenstein. Wzięto pod uwagę zarówno semiotyczny rodowód pojęcia, jak i jego podatność na uzupełnienia, modyfikacje i redefinicje. Ostatecznie w oparciu o teorię macierzy Brachy L. Ettinger zaproponowano zastąpienie przekładu intersemiotycznego kategorią transkryptum. Okazało się ono konceptem jak gdyby zaprojektowanym „oddolnie” przez sztukę i poezję ocalałej z Zagłady Rosenstein, dobrze oddającym ich wspólne związki, interferencje, wpływy. Do analizy wykorzystano wiersze i rysunki tuszem zawarte w książce poetyckiej Wszystkie ścieżki z 1978 roku oraz inne rysunki opublikowane w monografii Doroty Jareckiej i Barbary Piwowarskiej Erna Rosenstein. Mogę powtarzać tylko nieświadome / I can repeat only unconsciously (2014). Analiza ujawniła, że źródłem wielu dzieł artystki jest zapamiętany obraz śmierci rodziców zamordowanych przez szmalcownika w 1942 roku. Okazało się także, że artystka szuka sposobności, aby jednocześnie go ukryć i pokazać, w związku z czym na poziomie filozoficznym sięga po rozwiązania przypominające wspomniany koncept Ettinger, a na poziomie formalnym tworzy anamorfozy.

Słowa kluczowe: poezja; Zagłada; przekład intersemiotyczny; transkryptum; anamorfoza; rysunek tuszem; matka; córka

\section{| Abstract \\ MARTA TOMCzoK \\ From Inter to Trans: Dark Sources of Erna Rosenstein's Art}

The article examines the operability of the concept of intersemiotic translation in Emma Rosenstein's post-Holocaust poetry. Both the semiotic origin of the concept as well as its susceptibility to modification and re-definition were taken into account. Ultimately, based on the theory of Bracha L. Ettinger's matrix, it was proposed to replace the intersemiotic translation with the categories of transcriptum. It turned out to be a concept as if designed from the bottom up by the art and poetry of Rosenstein, the Holocaust survivors, reflecting well the interconnections and interferences. The analysis used poems and ink drawings included in the book 
of poetry All Paths from 1978, and other drawings published in the monograph by Dorota Jarecka and Barbara Piwowarska entitled Erna Rosenstein. I Can Repeat Only Unconsciously. (Warsaw: Foundation of the Foksal Gallery 2014). The analysis revealed that the source of many of the artist's works is the remembered image of the death of her parents murdered by a "szmalcownik" in 1942. It turned out that the artist was looking for an opportunity to hide it and show it at the same time, therefore on a philosophical level she reaches for solutions resembling the aforementioned concept by Ettinger and on a formal level she creates anamorphoses.

Keywords: poetry; Holocaust; intersemiotic translation; transcryptum; anamorphosis; ink drawing; mother; daughter

\section{| Nota o autorze}

Marta Tomczok - dr hab., badaczka Zagłady i jej najnowszych odniesień kulturowych. Pracuje na Wydziale Humanistycznym Uniwersytetu Śląskiego. Autorka m.in. książek: Czyja dzisiaj jest Zagłada? Retoryka - ideologia - popkultura (Warszawa 2017); Czy Polacy i Żydzi nienawidza się nawzajem? Literatura jako mediacja (Łódź 2019). Publikowała m.in. w „Tekstach Drugich”, „Pamiętniku Literackim”, „Porównaniach”, „Zagładzie Żydów. Studiach i Materiałach”, „Ruchu Literackim”, „Poznańskich Studiach Polonistycznych”. Jest redaktor naczelną „Narracji o Zagładzie".

E-mail: marta.tomczok@us.edu.pl

ORCID: 0000-0001-9512-007X 
